\begin{tabular}{|c|c|}
\hline$\underset{\text { REVIEW }}{A}$ & $\begin{array}{l}\text { ADVANCE RESEARCH JOURNAL OF SOCIAL SCIENCE } \\
\text { Volume } 11 \text { | Issue } 2 \mid \text { December, 2020 | 91-97 | ISSN-0976-5611 }\end{array}$ \\
\hline $0=$ & DOI: 10.15740/HAS/ARJSS/11.2/91-97 \\
\hline
\end{tabular}

\title{
Godly practices of the kani clique
}

\section{A. Sanitha Beevi}

P.G. Department of History, Iqbal College, Peringammala, Thiruvananthapuram (Kerala) India

(Email : sanithadanish@gmail.com)

\section{ARTICLE INFO :}

$\begin{array}{lll}\text { Received } & : & 18.09 .2020 \\ \text { Accepted } & : & 08.11 .2020\end{array}$

\section{KEY WORDS :}

Animism, Naturalism, Totemistic, Taboos, Magic, Polytheism

HOW TO CITE THIS ARTICLE :

Sanitha Beevi, A. (2020). Godly practices of the kani clique. Adv. Res. J. Soc. Sci., 11 (2): 91-97, DOI: 10.15740/HAS/ ARJSS/11.2/91-97.Copyright@ 2020:Hind Agri- Horticultural Society

\begin{abstract}
The religion of Kanikkar is largely grounded on animism, naturalism, Totemistic beliefs and taboos, magic polytheism. The supernatural powers largely guided their life. The Kanikkar believe that it is the spirit of their ancestors who protect them from the diseases, wild animals and furious of nature. In recent times, Hindu mythology also has found some places on their belief. They observe various rituals and ceremonies and offer worship and prayers to propitiate them. They gave more importance to religion in their life. They still believe in their forest deities and make offering to please the Gods and Goddesses. Thus, despite the spread of modernization, most of the Kanikkars adhere themselves to the age-old traditional customs and practices.
\end{abstract}

